\title{
PÁGINAS DE RECORDAÇÕES: RETRATO DE UM BRASIL DO SÉCULO XX
}

\author{
PÁGINAS DE RECORDAÇÕES: A PORTRAYAL OF A 20 ${ }^{\mathrm{TH}}$-CENTURY BRAZIL
}

\author{
Monica Chagas da Costa $^{1}$
}

\begin{abstract}
RESUMO: A presente resenha apresenta uma leitura das memórias de Floriza Barboza Ferraz, nascida no século XIX no interior de São Paulo. A narrativa da própria vida permite à autora ressaltar alguns aspectos da vida de uma esposa e filha de fazendeiros do café. Dois dos elementos mais salientes de sua história como é contada nas Páginas são sua relação com os trabalhadores - escravizados no período de sua infância, ou assalariados e majoritariamente imigrantes em sua época de casada - e sua visão sobre a maternidade e suas dificuldades durante as primeiras décadas do século XX.
\end{abstract}

PALAVRAS-CHAVE: Memórias; Escrita autobiográfica; Floriza Barboza Ferraz.

ABSTRACT: The present review presents a reading of Floriza Barboza Ferraz's memoir, a woman born in the $19^{\text {th }}$ century in the countryside of São Paulo. Her own life's narrative allows the author to highlight some elements of a coffee farmer's wife and daughter. Two of the most salient aspects of her story as it is told in Páginas are her relationships with workers - enslaved when she was a child, or hired, and mostly immigrants, when she was a married woman - and her view of maternity and its difficulties in the first decades of the $20^{\text {th }}$ century.

KEYWORDS: Memoir; Autobiographic writing; Floriza Barboza Ferraz.

FERRAZ, Floriza Barboza. Páginas de recordações: memórias. São Paulo: Editora Chão, 2020.

Páginas de recordações: memórias, escrito em 1947 por Floriza Barboza Ferraz, e publicado pela editora Chão em 2020, é uma obra resultante de um compilado das memórias de sua autora sobre sua vida no estado de São Paulo no final do século XIX e início do século XX. Posfaciado por Marina de Mello e Souza, o texto, escrito quando Floriza tem já 73 anos de idade, rememora a infância, a adolescência, o casamento e a vida de uma mulher que nasceu em uma fazenda de café e, ao casar, se muda para o interior paulista para estabelecer uma nova propriedade com o marido.

A narrativa é parcialmente fragmentada, contando com diferentes elementos para compor o quadro das lembranças de sua autora. Além da rememoração que concentra boa parte das duzentas e sessenta páginas do livro, há também poemas, fotos, cartas, páginas de jornal, e notas sobre os empregados de sua fazenda, que abrem e fecham a parte mais narrativa do relato. Essa colagem de lembranças funciona para realçar o subtítulo do livro, memórias. Para além da própria narrativa, Floriza confia também em outros elementos para recriar um espaço que já lhe é bastante distante.

1 Universidade Federal do Rio Grande do Sul - UFGRS, Porto Alegre, Rio Grande do Sul, Brasil; https://orcid.org/0000-0001-6340-6401; monicachagasdacosta@gmail.com. 
Presente e passado são uma questão em xeque desde o título da obra. As "páginas" de recordações são marcadas por um meio que é inevitavelmente posterior, e que empurra o relato para um ponto distante de seu autor. Esse espaço entre a matéria narrada e a autora é importante, e aparece por vezes na sintaxe declarativa que encolhe as frases e acelera o ritmo do texto. Isso se nota desde a primeira página: "Meus pais, Antônio Barboza Ferraz, e Ambrosina Ferraz de Campos, eram primos. Ele era natural da cidade de Campinas, e minha mãe, da cidade vizinha de Capivari no estado de São Paulo." (Ferraz, 2020, 9) O texto segue com frases semelhantemente construídas, estendidas pela inserção de nomes, mas de estrutura bastante simples.

No entanto, nos momentos em que a narração necessita de mais envolvimento emocional para dar profundidade e amplitude às cenas que descrevem a personalidade e as experiências de Floriza, as frases se dilatam, aumentando em poder descritivo e incluindo expressões mais corriqueiras da língua falada. Pode-se ver um exemplo no seguinte trecho, em que a menina Mimica (como era chamada a autora) desmaia de susto no pomar: "E, por pouco que o feitiço não virou contra o feiticeiro, pois nossa mãe estava para chegar do passeio e fina como era, iria perceber logo que algo havia acontecido com a sua Mimica [...]" (Ferraz, 2020, 27).

A vida da menina tem tom de Éden. A fazenda é cheia de árvores, flores e frutas que Floriza tenta recriar em sua nova vida depois de casada, mas leva muito mais tempo e esforço do que o esperado. Esse paralelo entre a vida na casa dos pais e as experiências na fazenda do marido fica claro durante a narrativa; há uma constante vontade de recriar as boas memórias da infância. No entanto, isso apresenta um problema para o leitor: a meninice de Floriza é no tempo da escravidão, e as boas memórias trazem por detrás os tons escuros da violência do regime. $\mathrm{O}$ medo aparece na descrição dos castigos dos negros que ela conhece quando pequena, e também se desloca para a figura do "negro velho fugido", usada para ameaçar os pequenos quando levados. O "negro fugido" é, de certa forma, também uma ameaça à propriedade e à figura paterna, na qual ela precisa conciliar a doçura de pai e a violência de senhor.

Quando mulher, o problema dos empregados continua perseguindo Floriza. Acompanhando os processos de imigrações de italianos, espanhóis e portugueses para o interior paulista no início do século XX, ela parece estranhar a distância que se cria entre patrão e empregado, muito diferente da relação quase familiar que ela projeta nos escravos do pai. $\mathrm{O}$ reconhecimento da humanidade dos negros de Rio Claro é problemático para Floriza, e, por vezes, é possível aproximar o modo como ela se refere a eles e o modo como fala dos cachorros que tem quando casada. Essa aproximação, interessantemente, é também um recurso de escritores do século XIX, entre eles o ilustre Machado de Assis, como, por exemplo, no conto "Verba Testamentária".

Já com a fazenda do marido estabelecida, Floriza consegue uma empregada doméstica com quem tem uma relação muito semelhante àquelas do tempo da escravidão. Ela chega a mencionar como o valor de nhá Tuda estava, para além de seus cuidados bastante maternais, em colocar a família da patroa quase acima da própria. Isso é mencionado no excelente posfácio de Marina de Mello e Souza: "Nhá Tuda é a trabalhadora doméstica que se assemelha à escrava e que ocupa espaço especial nas suas lembranças não só pelo auxílio por longo tempo prestado, mas por representar uma continuidade com o passado idílico da narradora." (Mello e Souza, 2020, 284)

Outro ponto importante da narrativa de Floriza parece ser sua ambivalência em relação a seu papel de mãe. A marca mais interessante que o texto traz é a escassa presença dos nomes de sua prole. Em geral, eles aparecem referidos por sua ordem de chegada (primeiro filho, segunda filha, etc.). Esse distanciamento aponta para uma falta de idealização da maternidade por parte da autora. Suas lembranças, ainda que carinhosas, não apagam as dificuldades pelas quais passa como uma jovem mãe, sozinha com o marido, longe do resto da família. As muitas 
doenças, buscas por médicos e preocupações gerais sobre o estado dos filhos são elementos que parecem tingir sua história de tons mais complexos que a imagem batida da mãe tradicional.

O texto de Floriza Barboza Ferraz permite um olhar mais claro sobre as dificuldades da maternidade nas condições precárias de novos assentamentos, e na formação de novos povoados no início do século XX. Sua trajetória ressalta a necessidade de elaboração de um senso de comunidade para dar conta de suas tarefas como mãe e esposa. A obra também ilumina as condições das mulheres fazendeiras do café e do algodão do início dos novecentos, e permite vislumbrar os complexos posicionamentos éticos e morais que elas negociavam, principalmente com relação a suas funções como mães e como patroas. Apesar de claro e direto, não é um texto simplório, mas uma rede de informações coletadas e coladas pelas mãos de uma matriarca que não permite que sua experiência seja achatada por lugares-comuns ou estereótipos fáceis.

\section{REFERÊNCIAS}

FERRAZ, Floriza Barboza. Páginas de recordações: memórias. São Paulo: Editora Chão, 2020 .

MELLO E SOUZA, Marina. Posfácio. In: FERRAZ, Floriza Barboza. Páginas de recordações: memórias. São Paulo: Editora Chão, 2020.

Monica Chagas da Costa, doutora em Letras pela Universidade Federal do Rio Grande do Sul, foi professora substituta do Instituto de Letras da Universidade Federal do Rio Grande do Sul, e atualmente atua no ensino privado como professora de língua inglesa.

Submetido em 10/06/2020

Aprovado em 15/07/2020 